\title{
REVIEW OF TURKISH KARST WITH EMPHASIS ON TECTONIC AND PALEOGEOGRAPHIC CONTROLS
}

\section{PREGLED KRASA V TURČIJI S POUDARKOM NA TEKTONIKI IN PALEOGEOGRAFIJI}

\author{
MEHMET EKMEKCI ${ }^{1}$
}

${ }^{1}$ International Research \& Application Center For Karst Water Resources, Hacettepe University, Beytepe 06532 Ankara Turkey

Prejeto / received: 1. 8. 2003 


\section{Abstract}

UDC: $551.44: 551.24(560)$

\section{Mehmet Ekmekci: Review of Turkish karst with emphasis on tectonic and paleogeographic controls}

This paper re-evaluates the karst phenomenon in Turkey basing on the controlling factors such as, the source of energy gradient, lithostratigraphy, type of erosion base and climate. Two major karst types described are a) evolutionary karst which implies continuous karstification but at different stage of maturation and b)rejuvenated karst which is formed by reactivating a formerly developed and subsequently ceased karst structure either by an uplift and/or a drastic decline of erosion base. Description of karst types considering both morphology and hydrogeology revealed that distribution of specific karst types is compatible with the neotectonic evolution of Turkey. Karst in all provinces except the Black Sea and Western Anatolian regions, is developed under the effect of the energy gradient provided by uplift. Different rates of uplift created different sub-types of karst. The climate effect was evaluated as a secondary factor for it has a role of shaping/re-shaping the karst forms rather than controlling the physical and chemical processes.

Key Words: karst, neotectonics, paleogeography, evolutionary karst, rejuvenated karst, Turkey.

\section{Izvleček}

UDK: 551.44:551.24(560)

\section{Ekmekci: Pregled krasa v Turčiji s poudarkom na tektoniki in paleogeografiji}

Prispevek ocenjuje kraške pojave v Turčiji na podlagi dejavnikov, kot so energija gradienta, litostratigrafija, vrsta erozijske osnove in podnebje. Opisani sta dve najpomembnejši vrsti krasa: a) »razvojna« vrsta krasa, ki vključuje neprekinjeno zakrasevanje v različnih stopnjah razvoja in b) »pomlajeni« kras, ko se je zaradi tektonskega dviga in/ali močnega spusta erozijske osnove ponovno spro•ilo zakrasevanje v sicer •e razvitem krasu, kjer pa je bil ta proces prekinjen. Opis vrst krasa, ob upoštevanju tako morfologije kot hidrologije, odkriva, da se razporeditev posameznih vrst krasa ujema z neotektonskim razvojem turškega ozemlja. Razen $\mathrm{v}$ črnomorski provinci in v zahodni Anatoliji, se je kras v vseh provincah razvijal pod vplivom energije gradienta zaradi dviga. Različni dvigi so vzrok različnim podvrstam krasa. Vpliv podnebja je obravnavan kot drugotni dejavnik, saj je to pomembnejše za oblikovanje/preoblikovanje kraških oblik kot pa za same fizikalne in kemijske procese.

Ključne besede: kras, neotektonika, paleogeografija, »razvojni« kras, »pomlajeni« kras, Turčija. 


\section{INTRODUCTION}

Turkey is located in the Middle-East and regarded as a natural bridge connecting Europe to Asia (Fig. 1), having one of her legs in Europe (Thrace) and the other in Asia (Anatolia), with a total surface area of $780532 \mathrm{~km}^{2}$. The eastern part of the country forms the high plateaus with an average altitude of about $2000 \mathrm{~m}$. At the western part low plains dominate, while Central Anatolia forms the closed basin type plateau with an altitude of $1000 \mathrm{~m}$. asl. with a very complex geological settings including all types of lithostratigraphical and structural elements.

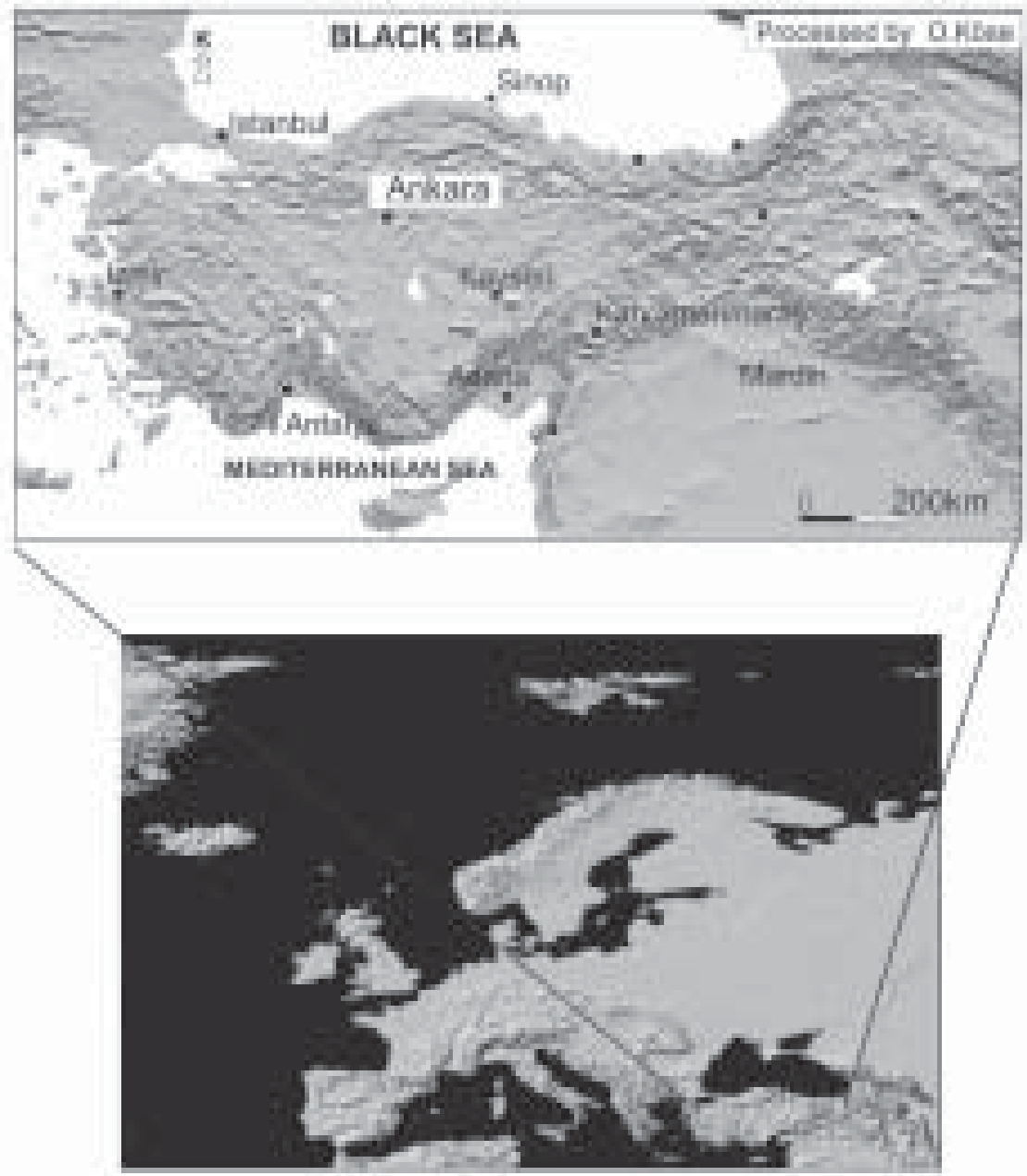

Fig. 1: Location of Turkey in Europe. 
This paper reviews the karst types in Turkey and to exhibit the compatibility between karst development and neotectonic and coeval paleogeographical evolution of the country. According to Şengör et. al. (1985), Turkey is located at "the western part of the tectonic escape system caused by post-collisional convergence of the Arabian Platform and Asia" and Early Miocene is taken as the starting point of the neotectonics in Turkey. According to the authors, the Serravallian period which is dated to about $12 \mathrm{Ma}$ is the beginning of a drastic change in the tectonics of Turkey. Since then, "the tectonics of Turkey has been dominated by the westward escape of an Anatolian block (scholle) mainly along the North and East Anatolian strike-slip faults (NAF and EAF respectively as shown in Fig. 2).

The authors explain the neotectonic evolution and the coeval paleogeographic development in five stages the first three of which correspond to Miocene while the last two Pliocene and Pleistocene-Present periods (Fig. 3).

\section{FACTORS CONTROLLING KARST IN TURKEY}

Among of great variety of factors controlling the karst phenomenon tectonics, petrography, source of energy gradient and the type of the erosion base are the major ones. Although climate is among the controlling factors, in Turkey, the geodynamics seems to dominate the climatic effects and makes it less pronounced almost throughout the country. However, the available data on the climatic effects are certainly incomplete to draw a conclusion in this regard.

Five factors were considered to control the major part karst processes:

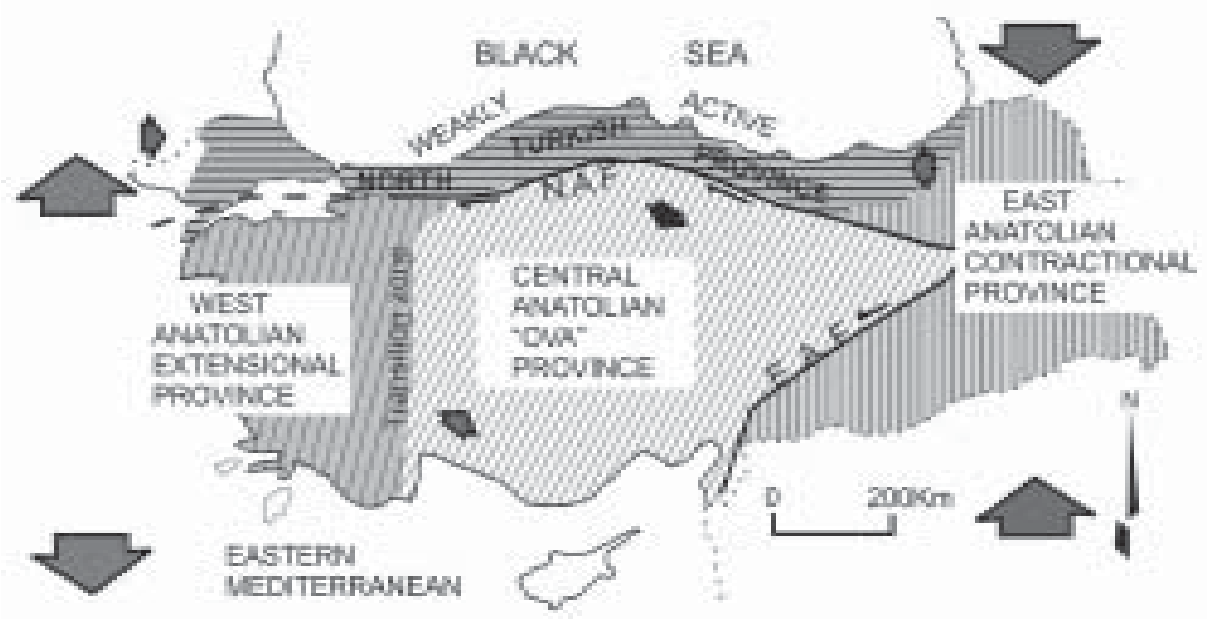

Fig. 2: Neotectonic Provinces of Turkey. Tips of Arrows Indicate the Direction of Movement. Their Size is Roughly Proportional to the Magnitude. (from Şengör et. al., 1985. with permission). 


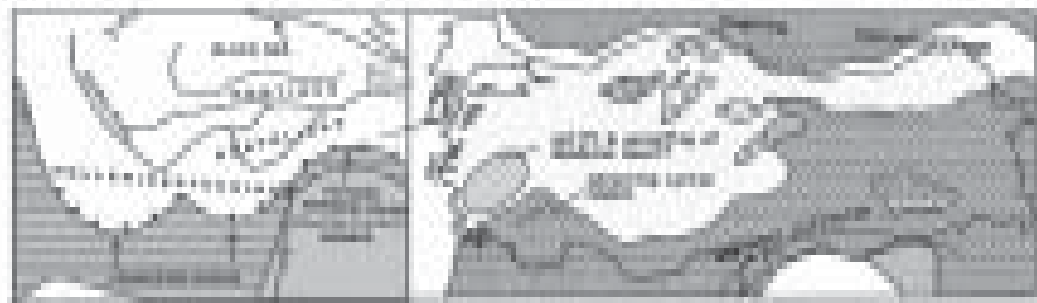

A
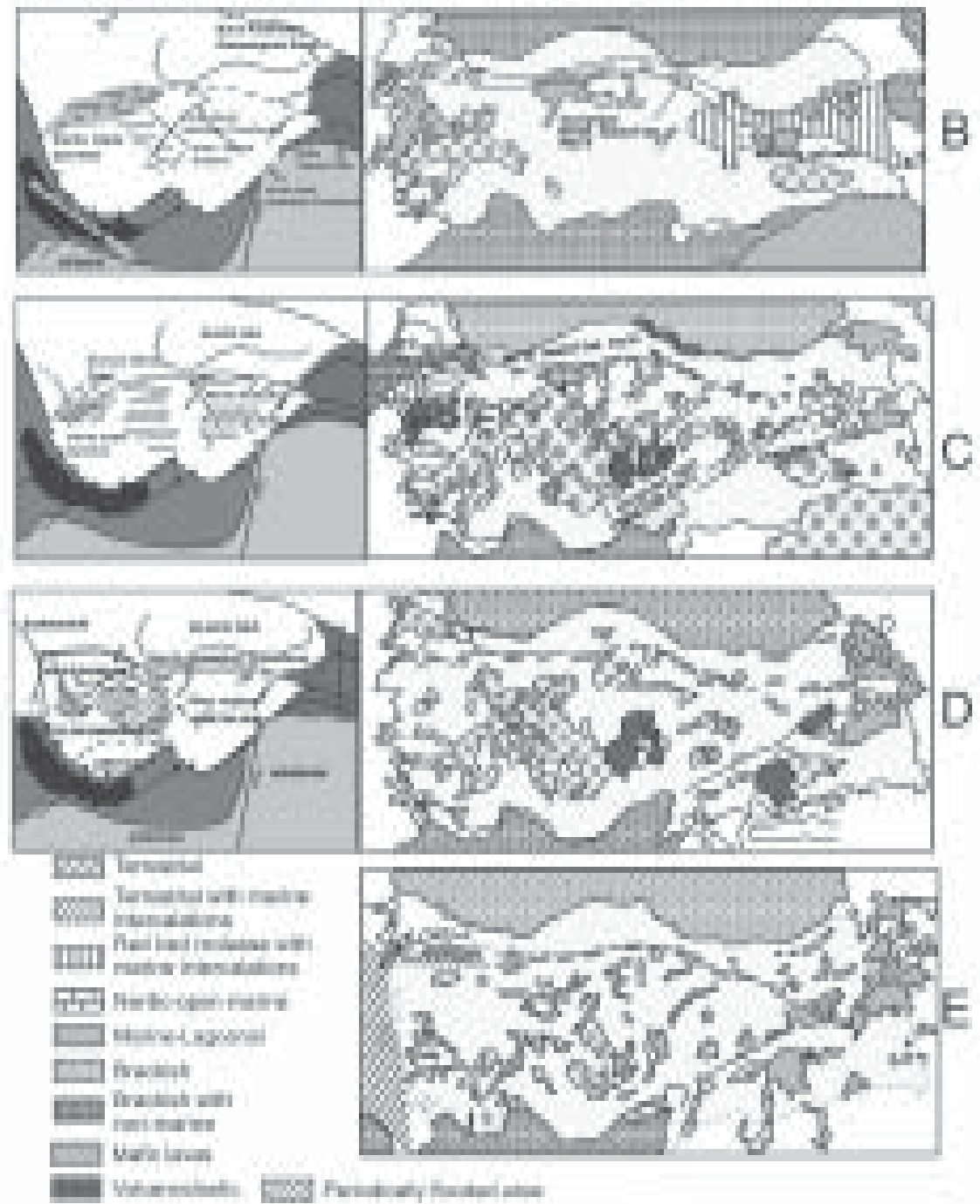

Fig. 3: Tectonic Evolution and Coeval Paleogeographic Development of Turkey (adapted from Şengör et.al., 1985. With permission). 
Lithology: Petrography, diagenesis and thickness are parameters considered in defining the lithology as a factor controlling karstification. Petrography implies here the origin of the rock weather detritic with impurities, organic or chemical.

Thickness is an important parameter that controls the karst process. However, thickness also reveals hints as to karst evolution when evaluated with other controlling parameters.

Tectonics: The tectonic effect was considered on the basis of the tectonic provinces defined by Şengör et. all. (1985). Uplift-submergence and contraction-extension are the parameters used in assessing the tectonic effect on karst.

Source of Energy Gradient: This factor includes implicitly the tectonic and the climatic effects. However, the karst types and their distribution in Turkey require a closer look to the source of energy gradient. Uplift, eustatic sea level changes, interior lake level fluctuations and river incision were considered to cause energy gradient that initiates and enhances karst development.

Erosion Base: Type of erosion base as a controlling factor may be the sea level, interior lake level, major river beds or an underlying impervious unit.

\section{OUTLINES OF TURKISH KARST}

When all factors that control karst processes are considered together, two major types of karst can be defined in Turkey: a) Evolutionary karst which implies continuous karstification but at different stage of maturation, and b) Rejuvenated karst formed by reactivating a formerly developed and subsequently ceased karst structures either by an uplift and/or a drastic decline of erosion base.

The major part of karst areas in Turkey are represented by evolutionary karst but with a great variety of sub-types depending on which controlling factor dominates the process. However, the author prefers to describe different karst types encountered in the country instead of defining subtypes, for the sake of simplicity and unambiguous explanation.

Evolutionary karst includes all types of karst from juvenile to relict and indicates that karstification processes have been effective without interruption, since the exposure of carbonate rocks to atmospheric conditions. Temporal variation in the intensity of karstification however is controlled by the rate of changes primarily in the energy gradient, climatic conditions and erosion base.

Rejuvenated karst features are common in certain parts of Turkey. This type of karst is distinguished where younger karst features are developed within older but interrupted karst (paleokarst). Interruption in karstification is due to inundation by mainly fresh water. Although inundation is closely related to the climatic changes, tectonic evolution and the coeval paleogeographic development controlled the areas inundated by fresh waters.

Description of karst according to the controlling factors is outlined below. The karst map produced based on this scheme is given in Fig. 4.

\section{Karst in Western Taurides (WTP)}

In the region that extends between the Aegean sea in the west and the Aksu thrust in the east, called as the Western Taurids, the karstifiable rocks are composed of mainly dense, massive recrystallized limestone of Mesozoic age.

Although the major part is covered by the authocthonous carbonates, allocthonous blocks of 


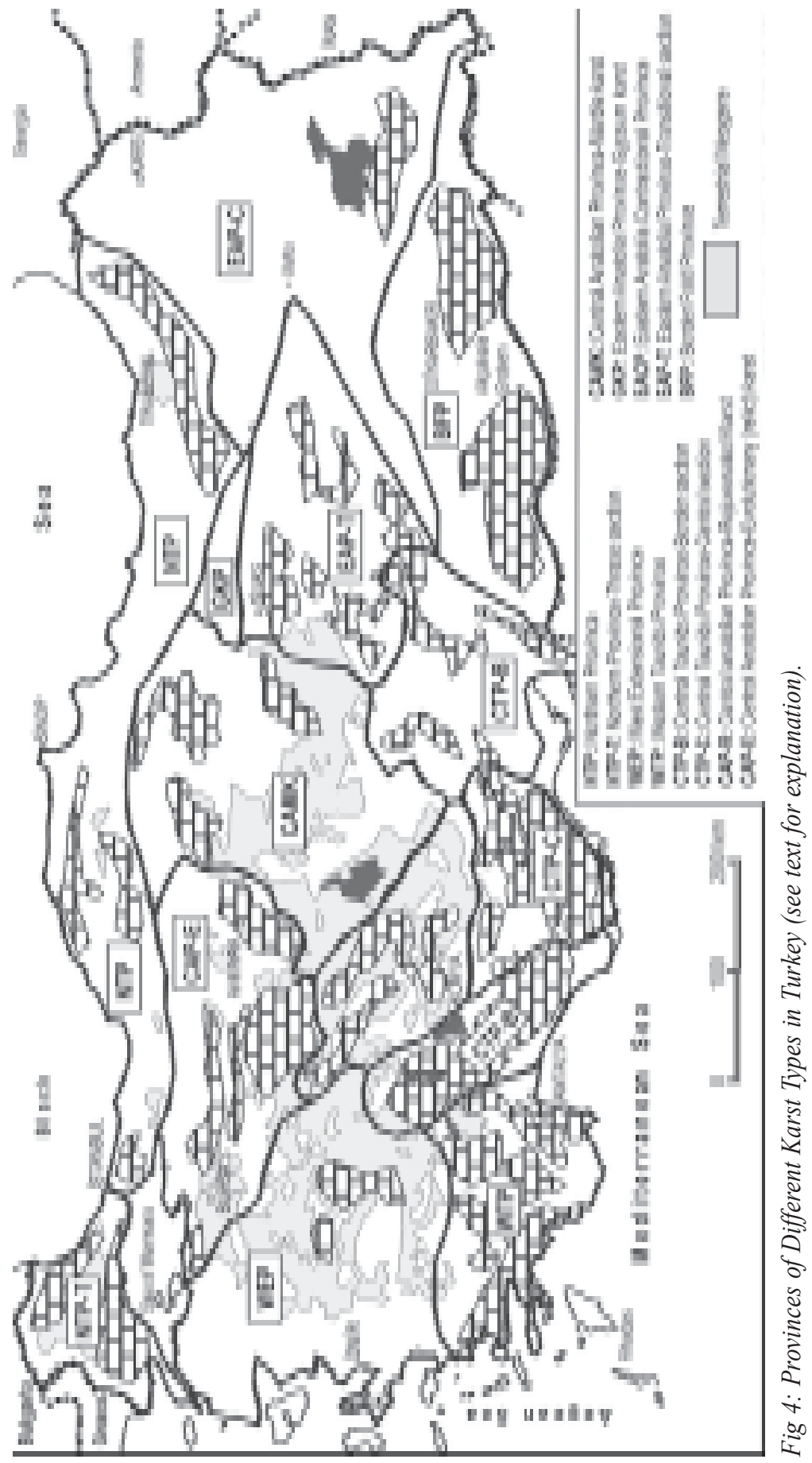


limestone within different nappes cover significant areas in the region. The size of the allocthonous carbonate rock masses ranges from some hundred meters to more than several kilometers, while the size of authocthonous units generally is over one kilometer.

According to the paleogeographical evolution, the carbonate rocks became exposed to atmospheric conditions since Late Miocene. Development of karst in the western Taurides therefore, might have started in Late Miocene. The carbonate rocks were not inundated by marine or fresh water which reveal that karstification has not been interrupted since then (see Fig. 3). Today, the carbonate rock masses have reached an elevation of more than $3500 \mathrm{~m}$. above the present sea level. Apparently, uplift has played the major role in providing a source of energy gradient that drove karstification processes until Late Pliocene-Early Pleistocene. The sea level was the regional erosion base for the authocthonous carbonate rocks, although impervious units that surround allochthonous limestone blocks mark the local erosion base. Owing to the rapid uplift, low content of impurities and large thickness, karst developed vertically to produce large scale features such as shafts, vertical to subvertical caves, sinkholes, ponors etc.

However, the present appearance of karst in Western Taurides in general is somewhat different from the karst developed until Late Pliocene-Early Pleistocene. This is because the region tectonically became under the influence of the West Anatolian Extensional regime due to the westerly escape of the Anatolian Scholle since Late Pliocene-Early Pleistocene (Fig. 3.e). This tectonic movement is resulted in a regional subsidence in Western Anatolia. The continuing subsidence had some major geomorphological and hydrogeological consequences. Together with the sea-level fluctuations, submergence of the formerly well-developed karst in the coastal area is resulted in formation of coastal and submarine springs, large karst depressions (poljes, uvalas, dolines) inundated by brackish waters. The dominating well-developed subsurface drainage suggests that the karst in this region is at its mature stage and can be regarded as holokarst.

In the east of the transition zone (see Fig. 2), the uplift is still continuing and has not been interrupted neither by change in tectonic regime nor by submergence by extensive water masses since Late Miocene. Therefore, karst in this region is still under intensive development that produces huge scale subterranean features such as underground rivers connected to large scale poljes and karstic lakes.

Climatic changes and the consequent sea-level fluctuations had secondary and/or local effects and the tectonic movements had the major role in karst development in the Western Taurides.

\section{Karst in Central Taurides (CTP)}

Unlike the Western Taurides, lithological units of Miocene age cover large areas in the Central Taurids. This is because the uplift level is not as high as it is in the Western and the Eastern Taurids which suggests that erosion had not been effective enough to remove the Miocene aged units. In addition to lithological diversity, the neo-tectonic evolution had different effects in different parts of the Central Taurids. As a consequence, two types of karst can be described within the Central Taurids on the basis of both origin and evolution. When the mapped karst types are evaluated together with the geodynamic evolution, it can be observed that the occurrence of different karst types is consistent with the tectonic setting. In order to perceive this consistency, the boundary of the Central Taurides is re-defined to include also the eastern area, and the thrust zone in the east (EAF) (see Fig. 2).

The karst massive in the west section and the karst massive in the east section are mainly 
composed of rocks older than Miocene. The central part is mainly covered by limestone of Miocene age and exhibit different types of karst. It is clear that the western and eastern sections where the Miocene units are eroded had been under the effect of the rapid uplift due to NE-SW contraction. Whereas extensional tectonics affected the central part. Therefore the uplift rate was slower in the central part.

Karst in central part (CTP-C) is developed in the Miocene biocalcarenitic limestone with relatively high content of impurity. Although the uplift provided the major source for energy gradient, the sea level fluctuations enhanced karstification. Therefore, the effect of climate is pronounced in karst development in this part of the province. In the meantime, the sea level in the south and the inland pluvial lakes in the north controlled the erosion base in general. Karstification encroached also into the underlying carbonate rocks that have been karstified before Miocene period. The combined effect of the uplift and sea level drop during glacial periods induced this encroachment whereby the formerly developed (paleo) karstic channels hosted the post-Miocene flow to enhance karstification. The deepest cave explored in Turkey so far (Peynirlik sinkhole: $1370 \mathrm{~m}$ ) is located in this province (http://www.bumak.boun.edu.tr). In addition coastal and submarine springs occurred subsequent to the rise of sea level during interglacial periods. Extensive features characterize karst in the Miocene limestones. Doline fields, uvalas and poljes are common whereas caves developed in this limestone are rather horizontal. However, when connected to the underlying karstic rocks, cavities may expand to form deep systems.

On the contrary, the western and eastern section of the Central Taurides (CTP-B) are characterized by the lack of extensive Miocene lithologies. This is also because these sections were not completely invaded by marine waters. Some patches of Miocene aged lithologies are of terrestrial character in general and they overlie the formerly karstified rocks of Mesozoic and Paleozoic age. Although the effect of uplift may be regarded as the principal source of energy gradient for post- Miocene karstification, there are several indications that karst developed during the paleo-tectonic (pre-Miocene) era in these sections. It is important to note that the major ores of paleokarst origin (boxite, lead) take place in the western and eastern sections of the Central Taurides (CTP-B).

Morphologically, the karst in these section is very similar to that in the area between Aksu thrust and Kýrkkavak fault in the Western Taurides. The only crucial difference is the existence of mineral ores related to paleokarst. In the eastern section (Aladag), rejuvenation of paleokarst can be traced in areas covered by Miocene aged terrestrial karstifiable deposits. Morphology of the juvenile karst of the Miocene deposits is shaped to a large extent by the combined effect of the rejuvenation and glacial processes. Deeply incised river beds such as the Manavgat river in the west and the Seyhan and Ceyhan Rivers in the east form the erosion base. Incision most probably has taken place in Plio-Quaternary. The modern karst flow which must be hosted by some paleo karstic channels is directed to these river beds.

\section{Karst in Southeast Anatolia (Border Folds Province-BFP)}

The area that is geographically defined as the 'Southeast Anatolia Region' fits well with the tectonically defined 'Border Folds Province'. Located at the border zone between the colliding plates (Arabian Platform moving toward the Anatolian Plate in the north), the tectonic contraction is pronounced in the province in the form of generally E-W extending folds and normal faults perpendicular to folding. From the tectonic evolution, it is evident that the province is under the 
effect of a general uplift. However, the paleogeographical development indicates that the region was under marine influence until Late Miocene (see Fig. 3.c). The erosive phase has been effective since then to remove the younger units so that lithological units of Paleogene age are exposed to terrestrial conditions initiating karst processes.

The carbonate rocks of Paleogene age are authocthonous, moderately thick-thick (up to 500 m.) chalky, cherty at upper levels and dolomitic at lower levels. The source of energy gradient for karstification is provided by both uplift and sea-level changes. Tectonically, the region is defined within the East Anatolian Contractional Province (Şengör et. al., 1985) which implies that it has been under compression. Compressive tectonic regime must have slowed down karstification except the areas that had experienced extensional compressional tectonics (e.g. Akcakale graben). Development of karst in Southeastern Anatolia was controlled by the major rivers (Euphrates and Tigris) incised as a consequence of the uplift. Impervious units underlying the carbonate rocks mark the erosion base where they are shallower. However, the riverbed of Euphrates and Tigris are the main erosion base for the area. Therefore major springs issue either in the river bed or along normal faults forming the grabens.

Owing to the compressive tectonic regime and the lithological characteristics of the Paleogene aged carbonate rocks, karst has been developed laterally rather than vertically. That is, extensive karst features such as dolines and uvalas are more common than deep caves and ponors. Where the impervious units are shallow, the erosion base is remained above the major river beds and these karstic features are captured by the surface drainage. Therefore, it is common to see karst in final stage (without subsurface drainage) neighbouring juvenile, mature karst in this province.

\section{Karst in Eastern Anatolia (EACP)}

The geographical Eastern Anatolia region can be subdivided into two sub-regions of distinct karst types. When dissimilar karsts are illustrated on a map, the subdivision is consistent with the tectonic map. As depicted in Fig. 2, the North Anatolian Fault (NAF) and the East Anatolian Fault (EAF) intersect in East Anatolia making an angle whose apex is toward east. It is possible to postulate that the neotectonic regime prevailed in a different way for the inside and outside areas of the angle. The outside area extending from the apex to the Iranian border in the east is defined as the East Anatolian Contractional Province. On the other hand, the area inside the angle is characterized by a transition from contraction to a fairly steady regime that characterizes the Central Anatolian 'Ova' Province, (Şengör et. al., 1985).

East Anatolian Contractional Province- EACP: Since Miocene period, Eastern Anatolia has been uplifted from contemporary sea level up to the present elevation of about $3000 \mathrm{~m}$. under the strong effect of the collision of the Arab plate. A major contraction has caused the metamorphic basement and the overlying Mesozoic units to uplift in the region. However, because this compression was accompanied by intensive volcanism during Miocene, lithological units of the metamorphic massifs were covered to a large extent by volcanic rocks and/or volcano-sedimentary deposits. Where not covered, the metamorphic massifs containing large areas of marbles exhibit typical marble karst as the common type with smooth topography lacking lateral karst features such as extensive dolines, uvalas or poljes, but instead with sinkholes and caves developed along the contact between marble and impervious metamorphic units. Therefore, stripe karst is also common.

The transition zone is re-defined in the sense of karst type as the Transition Province (EAP- 
T). The rocks that exhibit karst in this province are mainly authocthonous carbonates of Mesozoic age. Large part of the province was invaded by marine waters in Early Miocene. The uplift has started in Middle Miocene and the whole province became a terrestrial environment since Late Miocene. The paleogeographic development that was closely related to tectonic evolution indicates that the energy gradient provided by uplift for physical and/or chemical erosion was not as high as it is in the East Anatolian Contractional Province. Volcanic activity was not as extensive as it was in the East Anatolian Contractional Province either. Therefore, the carbonate rocks of Mesozoic age has not been completely eroded or covered by younger deposits. The terrestrial conditions initiated karstification in Middle Miocene at areas at elevations moderately above the contemporary sea level. The uplift has been relatively slow particularly at the northern section of the Transition Province where the evaporitic deposits of Oligocene - Early Miocene have not been completely eroded. Gypsum karst, is therefore extensive in the area (GKP).

Unlike the contractional province, in the transition province the karstic rocks are the Mesozoic carbonate rocks. It is evident from the tectonic and coeval paleogeographic evolution of the region that at the initiation phase of karstification, the erosion base was the sea level until Late Miocene. During Late Miocene the region has been uplifted and converted into completely terrestrial conditions. In Pliocene, the area continued to rise which strongly enhanced karstification. Development of subsurface drainage must have been started in Late Miocene and expanded during Pliocene. Drainage was directed toward the Mediterranean Sea and to the large lakes of Central Anatolia until Quaternary when the Euphrates and Tigris Rivers entrenched their bed within deep valleys. In Pleistocene, the erosion base turned out to be these major rivers and subsequently the subsurface drainage was diverted to these river beds.

\section{Karst in Central Anatolian Province (CAP)}

Central Anatolia can be divided into two subregions of distinct karst types (see Fig. 4). The northern and southern parts of the region exhibit remarkably different characteristics of karst both in terms of morphology and hydrology. The southern part is characteristic with its extensive cover of Miocene units. The northern part on the contrary, is lacking extensive cover and the preMiocene lithologies occupy large areas in the region with some limited cover of Pliocene terrestrial sediments. The appearance of karst is controlled to a great extent, by these characteristics in the region.

In Early Miocene, Central Anatolia was elevated above the contemporary sea level up to 2000 meters (see Fig. 3.a). This means that carbonate rocks of Mesozoic and Paleozoic age were effectively under karstification processes throughout the region. These conditions prevailed for the region until Late Miocene when a drastic change occurred between the northern and southern part of Central Anatolia. During Late Miocene, the southern part was flooded by tremendous amounts of fresh waters that formed the large Central Anatolian Pluvial Lakes. This flooding soaked the formerly developed karst. The effect of flooding gradually diminished northward. The most northern part, including the Sakarya River Basin, continued to expose to atmospheric conditions if not partly covered by terrestrial sediments. As an essential consequence, karst processes ceased in the southern part while the carbonate rocks in the northern part continued to karstify.

In the northern part (CAP-E), the impervious units became shallower as the steady(?) uplift continued. By the end of Pliocene, karst in carbonate rock masses was well developed. Similarly, the carbonates within the metamorphic units were subjected to karst processes where exposed to 
surface conditions. Due to the westerly escape of the Anatolian Scholle after intersection of the $\mathrm{NAF}$ and EAF, a transition zone between the Agean Graben system in the west and the tectonically weak Central Anatolian 'Ova' Regime in the east was developed. This tectonic regime sliced up the northern region during Pleistocene which was resulted in drastic changes of drainage. Another consequence linked to this tectonic regime was the dissection of large carbonate rocks that were formerly karstified into smaller pieces. The modern appearance of karst in the northern part of the Central Anatolian Province can be defined as 'dissected-relict' karst. The source for energy gradient since Pleistocene is the change of the Black Sea level. The northern region is drained mainly by the Sakarya River which is discharging into the Black sea. The impervious units underlying the carbonate rocks of Mesozoic age form the erosion base together with the Sakarya riverbed. On the other hand karst development in marbles within the metamorphic basement continue. Closer to the southern part, some of the formerly karstified carbonate rocks of Mesozoic age are covered by Pliocene sediments. As the uplift continue, these paleo-karstic features are revealed. All these features suggest that the karst is evolutionary in the northern part and karst of carbonate rocks of Mesozoic age is at its final stage.

As for the southern part (CAP-R), the advancing collision of the Levantine Ocean from the south and southwest, the Taurides continued to uplift rapidly particularly since Late Miocene. Situated adjacent to the Taurides, the southern part of Central Anatolian Province is affected thoroughly by the rapid uplift since Pleistocene. The continuous upward movement also affected the paleokarstic features by rising them to re-gain energy and involve in the hydrologic cycle again after long period of cessation. In areas where the Pleistocene tectonics faulted and fractured the Neogene overburden, the energy gained by rising caused rejuvenation of the buried karst. Two different landscapes were derived as a consequence: Multiphase karst and the 'Obruk' karst. Multiphase karst implies that karst developed at different periods are distinguishable in the rock masses of Mesozoic age. Development of a younger doline within a paleo-polje or paleo-doline is an example for the multiphase karst encountered in the southern part of Central Anatolian Province.

The Obruk karst is generally encountered on the the Neogene deposits that cover the paleokarstic openings. The 'Obruks'- a karstic feature similar to cenotes- are developed by sudden collapse. They may or may not contain groundwater and they may be in various size and depth. Although the Neogene deposits are mainly composed of limestone, collapses also seem to take place within the silty-sandy sediments. Obruks that were developed directly within the Neogene limestones generally contain groundwater whereas, those developed within the silty-sandy sediments are dry. This suggests that paleokarstic rocks underlying the Neogene karst aquifer have an essential role in Obruk development. Although the collapse occurs in the Neogene limestone, it is governed by the rise of the paleokarstic rocks producing a suffosion-like effect.

Based on all these observations, it is possible to conclude that there is a northward transition from 're-juvenated karst' to 'evolutionary karst' in the Central Anatolian Province (CAP-R).

\section{Karst in the Northern Province (NTP)}

The Northern Province covers the east-west extending Black Sea coast belt bordered by NAF from the south (see Fig. 4). Paleogeographically this province has never been invaded by marine waters since Early Miocene (see Fig. 3). Similarly, limnic and/or fluvial sediments are also lacking except in the central part of the Thrace peninsula (NTP-T). However, because this province is weakly active, and the energy gradient was controlled mainly by the Black sea level changes, the 
uplift is limited to the lesser east-west shortening which caused a much lower rate of erosion compared to other provinces. Accordingly, outcrops of carbonate rocks of Mesozoic age exist especially along the interior part of the province. Carbonate rocks of Paleozoic age crop out over a smaller area particularly in the western part of the province.

Karst of this province is of similar character to the 'classical karst'. Features such as dolines, poljes, caves, springs are common, but limited to the areal extension of the outcrops. Based on this paleogeographic evolution, evidently, no significant interruption of karst processes has been recorded in the province. However, karstification was controlled by the Black Sea level changes and therefore the effect of climatic changes is well pronounced in the province.

The western end of the province is characterized by carbonate rocks of Paleogene age overlying the units of the metamorphic basement. Karst developed in the carbonate rocks of Eocene age is controlled by the shallow impervious metamorphic units. The present appearance of karst in Paleogene rocks exhibits a typical example for the final stage of karst as the subsurface drainage is converted into surface drainage. Morphologically, the extensive karst features such as dolines and poljes are captured by recent streams and rivers.

\section{Karst in the Aegean Region (WEP)}

The Aegean region occupies the western part of Anatolia (see Fig. 4). This part of Anatolia has been the highland until the westerly escape of the Anatolian scholle started in Pleistocene. Therefore, major part of the lithologies covering the metamorphic Menderes Massif that form the basement were completely eroded in the central part. Nevertheless, at the periphery of the massif, outcrops of carbonate rocks of Mesozoic age still exist. These rock masses, together with the marbles of the metamorphic massif build up the karst in this province. Based on the paleogeographic evolution, karstification must have been developed during the paleotectonic era but interrupted during Middle Miocene to Pliocene by sedimentary basins (see Fig. 3).

\section{CONCLUDING REMARKS}

The review of Turkish karst outlined herein this paper is based on the inquiry on the principle underlying the distribution of different types of karst described by their morphologic and hydrologic characteristics. Mapping different types of karst revealed that the distribution was compatible with the tectonic map of the territory. Study of this map demonstrated that the processes that controlled karstification were closely related with the tectonic evolution and the coeval paleogeographic development of the country. Two major types of karst were described on the basis of this evolution: the evolutionary karst and the rejuvenated karst although evolutionary karst include several sub-types. Evolutionary karst implies that karst processes are continuous whereas the rejuvenated karst indicates an interruption in karstification. However, it was concluded that providing an insight on evolution of karst and the factors controlled karstification is much more useful than describing sub-types of karst. In this context, the territory is divided into seven main provinces to reconstruct the evolution of karst. Each province has its own tectonic and paleogeographic history and therefore, the development of karst has been specific to that province.

The complexity in tectonic evolution is reflected in development of karst particularly in the Taurus mountain range. It is not possible to consider the karst in Taurus range under one single class. This is not because of the lithological variety but because of the differences in type and magnitude of tectonic 
effects. Both evolutionary and rejuvenated karst types exist in the Taurus range. The western part of the Taurus range is under the effect of regional submergence. The formerly developed non-mantled karst, is being invaded by marine waters. As a consequence, the former vadose zone is becoming phreatic giving rise to occurrence of submarine karst features. Central Taurus region is more complex in terms of karst types. The eastern and western border sections of the Central Taurus region is characterized by rapid uplift, whereas the central part is under the effect of a slower uplift. Therefore, in central part of the region, juvenile, evolutionary karst is common while at the border sections are characterized by paleokarst and rejuvenated karst. Eastern Anatolia has been submerged by marine waters until Middle Miocene. The uplift of Eastern Anatolia caused the exposure of older lithologic units, some of which karstified. The continuous uplift also caused erosion of the units covering the metamorphic basement which also contain marbles. Therefore, apart from limestone karst, marble karst is also common in the Eastern Anatolian region. Westward escape of the Anatolian scholle following the intersection of the Northern Anatolian Fault and the Eastern Anatolian Fault, lessen the rate of uplift and therefore the rate of erosion. Southeastern Anatolia is the border folds province which has been under a compressional tectonic regime since Early Miocene. However, the uplift is slower and karst is developed in limestones of Paleogene age. Capture of karst depressions by the tributaries of Euphrates and Tigris rivers which incised their beds suggests that the erosion base in this region is controlled by the main drainage systems. The weakly active Central Anatolian province exhibits the best examples of rejuvenated karst. However, evolutionary karst also exists in areas that are not covered by Miocene deposits. In these areas karst has almost completed its evolution. The impervious units are very shallow, and the carbonate rock masses are dissected by the drainage network. This is the reason of having relict karst in the northern and northwestern part of the Central Anatolian Province. Similarly, the Balck Sea region is tectonically weakly active but the karst is evolutionary and controlled mainly by the Black Sea level changes.

Finally, it is essential to note that this scheme requires refinement by more local studies on karst description and reconstruction of karst evolution. Studies towards this sort of substantiation should be planned under an overall project including dating cave deposits and other quantitative data collection on paleoenvironmental and paleoclimatic records.

\section{REFERENCE}

Erol, O., 1981, Neotectonic and Geomorphological Evolution of Turkey, Zeitschrift für Geomorphologie, Neue Folge, Supplement Band 30.

Eroskay S.O., And Gunay, G., 1979, Tecto-genetic Classification and Hydrogeological Properties of the Karst Regions in Turkey., Proc. Of. Int. Sem. On Karst Hydrogeology-Antalya Turkey

Herak, M., 1977, Tecto-genetic Approach to the Classification of Karst Terrains. KRS Jugoslavie, 9/3, Yugoslavia

Ketin I., 1966, Tectonic Units of Anatolia, MTA Publications No. 66, Ankara (in Turkish)

Özgül N., 1983, Stratigraphy and Tectonic Evolution of Central Taurides. In Proc. of Int. sym. on Geology of the Taurus Belt, (eds: Tekeli O. \& Göncüođlu M.C.) 26-29 Sept. Ankara-Turkey.

Țengör A.M.C., Görür, N. and Ţarođlu, F., 1985, Strike-Slip Faulting and Related Basin Formation in Zones of Tectonic Escape: Turkey as a Case Study, Society of Economic Paleontologists and Minberalogists Special Publication No. 37. 